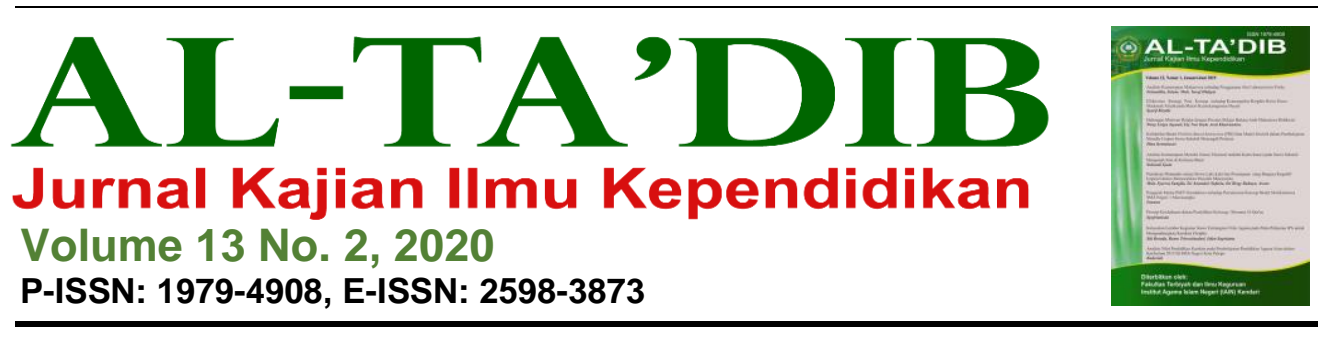

\title{
Gambaran Kesenangan Belajar IPA dan Ketertarikan Berkarir di Bidang IPA Siswa Sekolah Menengah Pertama
}

\author{
Nirmala Sari ${ }^{1}$, Erika $^{2}$ \\ ${ }^{1}$ Universitas Jambi, Indonesia. E-mail: nirmalasari311998@gmail.com \\ ${ }^{2}$ Universitas Jambi, Indonesia. E-mail: erk.erika@gmail.com
}

\author{
ARTICLE INFO \\ Keywords: \\ Attitude; career; interest; \\ junior high school; \\ learning enjoyment \\ How to Cite: \\ Nirmala, S., \& Erika. \\ (2020). Gambaran \\ kesenangan belajar IPA \\ dan ketertarikan berkarir di \\ bidang IPA siswa sekolah \\ menengah pertama. $A l$ - \\ Ta'dib: Jurnal Kajian Ilmu \\ Kependidikan, 13(2), 103- \\ 112.
}

\begin{abstract}
This article aims to present the results of research on students' attitudes towards science subjects in terms of two indicators, namely interest in learning science and career interest in science among junior high school students. This associative quantitative research uses a survey on a research sample of 128 students. The data analysis technique used is descriptive statistics. The results of the data analysis showed that the students' attitudes on the indicators of interest in learning science were dominant in the good category, while the attitudes of the students on the indicators of career interest in science were dominant in the moderate category.
\end{abstract}


INFORMASI ARTIKEL

Kata Kunci:

IPA; karir; kesenangan

belajar; ketertarikan;

sekolah menengah

pertama; sikap

Cara Mensitasi:

Nirmala, S., \& Erika.

(2020). Gambaran

kesenangan belajar IPA

dan ketertarikan berkarir di

bidang IPA siswa sekolah

menengah pertama. $\mathrm{Al}$ -

Ta'dib: Jurnal Kajian Ilmu

Kependidikan, 13(2), 103-

112.

\begin{abstract}
ABSTRAK
Artikel ini bertujuan menyajikan hasil penelitian atas sikap siswa terhadap mata pelajaran IPA ditinjau melalui dua indikator yaitu kesenangan dalam belajar IPA dan ketertarikan berkarir di bidang IPA pada siswa sekolah menengah pertama. Penelitian kuantitatif asosiatif ini menggunakan survey pada sampel penelitian sebanyak 128 siswa. Teknik analisa data yang digunakan ialah statistik deskriptif. Hasil analisa data menunjukkan bahwa sikap siswa pada indikator kesenangan dalam belajar IPA dominan berkategori baik, sedangkan sikap siswa pada indikator ketertarikan berkarir di bidang IPA dominan berkategori cukup.
\end{abstract}

\section{Pendahuluan}

Di Indonesia, mata pelajaran ilmu pengetahuan alam (IPA) diajarkan sebagai mata pelajaran wajib mulai dari sekolah dasar sampai dengan sekolah menengah atas. Muatan pelajaran IPA yang terbentuk dari fakta, konsep, prinsip, hipotesis, teori dan model mengajak siswa untuk belajar merumuskan konsep berdasar fakta-fakta empiris di lapangan. Hal ini menjadikan mata pelajaran IPA sebagai bahan penelitian yang menarik. Secara global, dalam beberapa dekade terakhir, pendidik, peneliti, dan pengambil keputusan mulai memberi perhatian pada aspek afektif di mata pelajaran IPA (OECD, 2016). Penelitian tentang sikap siswa terhadap mata pelajaran IPA telah banyak dilakukan dan sangat beragam (Astalini \& Kurniawan, 2019; Astalini, Kurniawan, Perdana, \& Patoni, 2019; Jufrida, Kurniawan, Astalini, Darmaji, Kurniawan, \& Maya, 2019; Sheldrake, 2020). Fokus penelitian terkait sikap siswa dan faktor lain yang dikaitkan dengan ketertarikan berkarir di bidang IPA menunjukkan bahwa hal ini telah menjadi perhatian besar bagi peneliti (DeWitt, Archer, \& Osborne, 2014; DeWitt, Osborne, Archer, Dillon, Willis, \& Wong, 2013; Falentini, Taufik, \& Mudjiran, 2013; Manasia, 2015; Potvin \& Hasni, 2014; Swarat, Ortony, \& Revelle, 2012; Tyler-Wood, Ellison, Lim, \& Periathiruvadi, 2012).

Sikap siswa terhadap mata pelajaran IPA dipengaruhi oleh proses pembelajaran dan berbagai hal lainnya. Ada dua faktor yang dapat memengaruhi proses pembelajaran yaitu faktor internal dan faktor eksternal. Faktor internal berupa minat, motivasi belajar, sikap, kebiasaan belajar, dan 
konsep diri, sedangkan faktor eksternal berupa lingkungan sekolah, teman sebaya, suasana kelas, kurikulum sekolah, fasilitas, dan infrastruktur (Kurniawan, Astalini, \& Anggraini, 2018). Faktor internal seperti sikap sangat memengaruhi proses pembelajaran. Sikap positif berupa kecenderungan tindakan seseorang yang mengarah untuk mendekati, menyenangi, dan mengharapkan obyek-obyek tertentu. Sedangkan sikap negatif merupakan kecenderungan tindakan seseorang yang mengarah untuk bermalas-malasan, ceroboh, boros, tidak disiplin dan sebagainya pada obyekobyek tertentu. Sikap dalam pembelajaran sangatlah penting, begitu pun dengan sikap yang ada pada pembelajaran terhadap mata pelajaran IPA (Astalini, Kurniawan, \& Putri, 2018). Sikap senang siswa terhadap IPA dapat ditunjukkan bagaimana siswa bersikap terbuka dan semangat terhadap mata pelajaran IPA di dalam atau pun di luar kelas (Kurniawan, dkk., 2018).

Sikap positif terhadap suatu pelajaran harus dimiliki oleh siswa untuk memperoleh hasil belajar yang diharapkan. Kenyataannya, tidak semua siswa memiliki sikap positif karena adanya perbedaan-perbedaan individual. Perbedaan individual dalam dunia pendidikan yang memengaruhi sikap siswa terhadap pelajaran diantaranya perbedaan etnis/ras, jenis kelamin atau gender, lingkungan dan budaya (Bang \& Baker, 2013). Untuk mengukur sikap siswa terhadap mata pelajaran IPA diperlukan suatu indikator. Indikator yang bisa digunakan adalah kesenangan dalam belajar IPA dan ketertarikan berkarir di bidang IPA. Penelitian yang dilakukan oleh Astalini, dkk. (2018) menemukan bahwa ketertarikan berkarir di bidang IPA pada siswa sekolah menengah pertama (SMP) berkategori cukup dengan persentase sebesar 41,8\%. Artinya, hampir sebagian siswa ingin melanjutkan karirnya di bidang IPA. Sejalan dengan hal itu, Sofyan, Yusuf, dan Daharnis (2018) menemukan bahwa siswa laki-laki memiliki ambisi karir di bidang IPA yang lebih besar dibanding dengan siswa perempuan. Penelitian Bang dan Baker (2013) mengonfirmasi bahwa siswa laki-laki menunjukkan sikap lebih positif terhadap mata pelajaran IPA dan keinginan berkarir di bidang IPA.

Penelitian ini, meskipun masih sangat jarang dilakukan di Indonesia, merupakan penelitian kuantitatif asosiatif dengan indikator bersumber dari penelitian Fraser (1981) yang kemudian diimplementasikan di Indonesia melalui penelitian Astalini dan Kurniawan (2019). Tujuan penelitian ini adalah untuk mengetahui gambaran sikap siswa terhadap mata pelajaran IPA yang ditinjau berdasarkan indikator kesenangan dalam belajar IPA dan ketertarikan berkarir di bidang IPA pada siswa SMP di Kota Jambi, Indonesia. Penelitian ini dapat berkontribusi dalam meningkatkan sikap positif siswa terhadap mata pelajaran IPA di lembaga pendidikan SMP. Selain itu, hasil penelitian ini juga dapat membantu guru IPA dalam mendesain pembelajaran agar dapat meningkatkan sikap siswa terhadap IPA 
secara efektif. Secara luas, penelitian ini juga akan mengonfirmasi temuan penelitian lain yang menemukan bahwa ada hubungan yang sangat erat antara perilaku terhadap mata pelajaran IPA dengan keinginan berkarir di bidang IPA (DeWitt \& Archer, 2015; DeWitt, dkk., 2013).

\section{Metode Penelitian}

Penelitian ini dilakukan di salah satu SMP negeri di Kota Jambi, Indonesia dan melibatkan 128 siswa sebagai responden. Penelitian ini adalah penelitian kuantitatif asosiatif menggunakan metode survei atau angket tertutup yang memaparkan sikap positif dan negatif siswa SMP terhadap mata pelajaran IPA. Instrumen ini menggunakan dua indikator yang diadaptasi dari penelitian Astalini dan Kurniawan (2019) dengan sebanyak 18 pernyataan yang memiliki Cronbach Alpha sebesar 0,842. Nilai Cronbach Alpha tersebut berada pada rentang 0,80-1,00 yang menunjukkan tingkat reliabilitas yang sangat tinggi sehingga instrumen tersebut layak digunakan. Skala yang digunakan pada instrumen angket sikap adalah skala Likert lima poin yang terdiri atas STS = sangat tidak setuju dengan skor 1 , TS = tidak setuju dengan skor $2, \mathrm{~N}=$ netral dengan skor $3, \mathrm{~S}=$ setuju dengan skor $4, \mathrm{SS}=$ sangat setuju dengan skor 5. Adapun indikator dan rentang yang digunakan pada angket sikap ditampilkan pada Tabel 1. Data yang diperoleh melalui angket kemudian dianalisis menggunakan SPSS dan analisis statistik deskriptif.

Tabel 1. Indikator Pernyataan Angket Sikap terhadap Mata Pelajaran IPA

\begin{tabular}{cccc}
\hline \multirow{2}{*}{ Kategori } & Rentang & $\begin{array}{c}\text { Kesenangan dalam } \\
\text { Belajar IPA }\end{array}$ & $\begin{array}{c}\text { Ketertarikan Berkarir di } \\
\text { Bidang IPA }\end{array}$ \\
\hline Sangat Tidak Baik & $9.0-16.2$ & & \\
Tidak Baik & $16.3-23.4$ & $1,2,5,6,8,10,12$, & $3,4,7,9,11,13,14,15$, \\
Cukup & $23.5-30.6$ & 16,18 & 17 \\
Baik & $30.7-37.8$ & & \\
Sangat Baik & $37.9-45.0$ & & \\
\hline
\end{tabular}

\section{Hasil dan Pembahasan}

\subsection{Kesenangan dalam Belajar IPA}

Hasil deskripsi kesenangan dalam belajar IPA pada Tabel 2 menunjukkan bahwa distribusi hasil tidak merata. Proporsi dominan indikator kesenangan dalam belajar IPA berada pada rentang 30.7-37.8 yang menunjukkan kategori baik dengan persentase 56.3\% (72 dari 128 siswa). 
Tabel 2. Deskripsi Kesenangan dalam Belajar IPA

\begin{tabular}{llcc}
\hline No & Rentang & Frekuensi & Persen(\%) \\
\hline 1 & $9.0-16.2$ & 0 & 0 \\
2 & $16.3-23.4$ & 10 & 7.8 \\
3 & $23.5-30.6$ & 42 & 32,8 \\
4 & $30.7-37.8$ & 72 & 56.3 \\
5 & $37.9-45.0$ & 4 & 3.1 \\
& Jumlah & 128 & 100 \\
\hline
\end{tabular}

Hal ini juga ditunjukkan pada hasil temuan dalam penelitian ini bahwa kebanyakan siswa memberikan respon baik pada pernyataan "Pelajaran IPA menyenangkan", "Sekolah harus memiliki pelajaran IPA lebih banyak setiap minggu", "Saya senang pergi ke tempat belajar IPA". Dengan begitu dapat dikatakan bahwa siswa memiliki kesenangan yang baik dalam belajar IPA. Siswa yang memiliki perasaan senang atau suka dalam hal tertentu cenderung mengetahui hubungan antara perasaan dengan minat (Pratiwi, 2015). Ketika siswa senang pada mata pelajaran IPA tentu akan memusatkan perhatiannya lebih banyak pada pelajaran IPA. Kemudian, karena pemusatan perhatian yang intensif terhadap mata pelajaran itulah yang memungkinkan siswa untuk belajar lebih giat dan akhirnya mencapai prestasi yang diinginkan (Pratiwi, 2015). Ini juga berati bahwa jika siswa merasa bahwa pelajaran IPA menyenangkan maka mereka akan lebih bisa mempertahankan minat belajar IPA mereka dan juga akan lebih mudah memahami muatan materi pelajaran IPA (Swarat, dkk., 2012).

Kesenangan belajar dalam IPA dapat diartikan bahwa setiap siswa yang memiliki sikap positif terhadap sains memiliki kenyamanan dan merasakan kesenangan. Siswa menilai 'kesenangan' mereka dari kegiatan yang diukur dengan indikator benci, tidak suka, tidak peduli, suka, dan cinta, sementara guru menilai 'kegunaan' dari setiap aktivitas (Maharaj-Sharma \& Sharma, 2017). Oleh karena itu, kesenangan siswa saat proses belajar sains dapat dilihat dari bagaimana siswa menanggapi pembelajaran tersebut. Secara umum, indikator kesenangan dalam pembelajaran sains diekspresikan dengan senang atau tidak senang dan suka atau tidak suka. Siswa yang senang dengan pelajaran IPA akan berminat untuk belajar IPA yang mereka perlukan untuk meningkatkan minat belajar mereka.

Siswa yang menyukai atau senang dengan pelajaran IPA tentu akan tertarik untuk menambah waktu belajarnya karena mereka akan tertarik mencari tahu lebih jauh mengenai hal yang mereka senangi tersebut. Hal ini juga berlaku untuk pelajaran IPA. Siswa yang menyenangi pelajaran IPA akan mencari lebih dalam tentang materi yang dijelaskan guru. Hal ini akan membentuk proses pembelajaran mandiri siswa dengan baik dan akan 
memengaruhi hasil belajar siswa di sekolah dengan adanya penambahan waktu belajar lain selain di kelas.

\subsection{Ketertarikan Berkarir di Bidang IPA}

Dari hasil deskripsi ketertarikan berkarir di bidang IPA yang ditunjukkan pada Tabel 3 terlihat bahwa distribusi hasil tidak merata karena proporsi dominan berada pada rentang 23.5-30.6 yang menunjukkan kategori cukup dengan persentase 59.4\% (76 dari 128 siswa). Hal ini dapat disimpulkan bahwa sikap siswa untuk indikator ketertarikan berkarir di bidang IPA adalah kategori cukup. Hal penelitian ini juga menunjukkan bahwa rata-rata siswa memberikan respon cukup baik pada pernyataan "Ketika saya lulus sekolah, saya ingin bekerja dengan orang-orang yang membuat penemuan dalam bidang IPA" dan "Pekerjaan sebagai ilmuwan akan menarik". Hasil penelitian ini sejalan dengan penelitian Astalini, dkk. (2018) bahwa ketertarikan berkarir di bidang IPA pada siswa SMP berkategori cukup baik.

Tabel 3. Deskripsi Ketertarikan Berkarir di Bidang IPA

\begin{tabular}{llcc}
\hline No & Rentang & Frekuensi & Persen $(\%)$ \\
\hline 1 & $9.0-16.2$ & 0 & 0 \\
2 & $16.3-23.4$ & 24 & 18,8 \\
3 & $23.5-30.6$ & 76 & 59,4 \\
4 & $30.7-37.8$ & 24 & 18,8 \\
5 & $37.9-45.0$ & 4 & 3,1 \\
& Jumlah & 128 & 100 \\
\hline
\end{tabular}

Siswa SMP merupakan siswa yang memasuki usia remaja awal dimana perencanaan karir sangat dibutuhkan mengingat masa ini adalah awal dimulainya perencanaan untuk mencapai rencana selanjutnya dalam karir (Saridewi \& Naqiyah, 2017). Siswa di salah satu SMP negeri dalam penelitian ini cukup memiliki ketertarikan berkarir di bidang IPA. Artinya, mereka sudah mempunyai rencana untuk melanjutkan pendidikan di masa depan pada bidang IPA. Hal ini sejalan dengan yang dilaporkan oleh Maison, Astalini, Kurniawan, dan Sholihah (2018) bahwa seseorang yang memiliki minat, kemampuan dan kepercayaan diri terhadap suatu bidang akan cenderung memiliki keinginan berkarir di dalamnya. Pengalaman positif siswa saat belajar IPA akan menimbulkan ketertarikan atau kesenangan siswa belajar IPA yang kemudian akan memungkinkan mereka memilih berkarir di bidang IPA (Aschbacher, Li, \& Roth, 2010; DeWitt, dkk., 2013). Sebaliknya, siswa yang memiliki sikap negatif terhadap mata pelajaran IPA akan sulit untuk memilih jalur karir di bidang IPA (Shin, Rachmatullah, Roshayanti, Ha, \& Lee, 2018). 
Ketertarikan untuk melanjutkan karir di bidang IPA tidak lepas dari seberapa besar individu tersebut memiliki keyakinan bahwa berkarir di bidang IPA merupakan salah satu keinginan untuk masa depannya (Astalini, dkk., 2018). Selain itu, ketertarikan memilih karir di bidang IPA di masa depan juga sangat ditentukan pada seberapa besar paparan pelajaran IPA pada siswa SMP ataupun sekolah menengah atas (SMA) (Wang, 2013). Pilihan karir di bidang IPA seperti guru IPA, dokter, farmasi dan sebagainya menjadi pertimbangan siswa dalam memilih berkarir di bidang ini. Siswa SMP memandang bahwa berkarir di bidang IPA cukup menjanjikan, terlebih lagi dengan pertumbuhan sains di Indonesia yang semakin luas dan cepat (Shin, dkk., 2018).

\section{Kesimpulan}

Penelitian mengenai sikap siswa SMP terhadap mata pelajaran IPA yang ditinjau berdasarkan dua indikator sikap ini menunjukkan bahwa indikator kesenangan dalam belajar IPA dominan berkategori baik sedangkan indikator ketertarikan berkarir di bidang IPA dominan berkategori cukup. Siswa yang memandang IPA secara positif menunjukkan tingkat kesenangan yang baik dalam belajar IPA dan memiliki ketertarikan yang baik untuk berkarir dibidang IPA. Sebaliknya, peserta didik yang memandang IPA secara negatif umumnya tidak memiliki rasa senang dalam belajar IPA bahkan tidak memiliki minat yang baik untuk berkarir di bidang IPA. Penelitian ini masih memerlukan penggalian dan analisis data yang lebih mendalam untuk dapat menggambarkan secara utuh tentang kesenangan belajar IPA dan ketertarikan berkarir di bidang IPA, khususnya siswa SMP yang nantinya dapat menjadi representasi populasi yang lebih luas. Beberapa faktor terkait penelitian ini, misalnya, perbedaan latar belakang ekonomi siswa terhadap sikap pada pelajaran IPA, perbedaan gender terhadap mata pelajaran IPA dan pilihan karir di bidang IPA merupakan bagian yang dapat dijadikan fokus pada penelitian-penelitian berikutnya.

\section{Ucapan Terima Kasih}

Peneliti mengucapkan terimakasih kepada kepala sekolah, guru, serta siswasiswi pada sekolah yang telah memberikan izin dan membantu peneliti dalam menyelesaikan penelitian ini.

\section{Daftar Pustaka}

Aschbacher, P. R., Li, E., \& Roth, E. J. (2010). Is science me? High school students' identities, participation and aspirations in science, 
engineering, and medicine. Journal of Research in Science Teaching, 47(5), 564-582. https://doi.org/10.1002/tea.20353

Astalini, A., \& Kurniawan, D. A. (2019). Pengembangan instrumen sikap siswa sekolah menengah pertama terhadap mata pelajaran IPA. Jurnal Pendidikan Sains, 7(1), 1-7. https://doi.org/10.26714/jps.7.1.2019.1-7

Astalini, Kurniawan, D. A., Perdana, R., \& Patoni, H. (2019). Identifikasi sikap peserta didik terhadap mata pelajaran fisika di Sekolah Menengah Atas Negeri 5 Kota Jambi. Unnes Physics Education Journal, 8(1), 3443. https://doi.org/10.15294/upej.v8i1.29510

Astalini, Kurniawan, D. A., \& Putri, A. D. (2018). Identifikasi sikap implikasi sosial dari IPA, ketertarikan menambah waktu belajar IPA, dan ketertarikan berkarir di bidang IPA siswa SMP se-Kabupaten Muaro Jambi. Jurnal Tarbiyah: Jurnal Ilmiah Kependidikan, 7(2), 93108.

Bang, E., \& Baker, D. R. (2013). Gender differences in Korean high school students' science achievements and attitudes towards science in three different school settings. Mevlana International Journal of Education, 3(2), 27-42. https://doi.org/10.13054/mije.13.11.3.2

DeWitt, J., \& Archer, L. (2015). Who aspires to a science career? A comparison of survey responses from primary and secondary school students. International Journal of Science Education, 37(13), 2170 2192. https://doi.org/10.1080/09500693.2015.1071899

DeWitt, J., Archer, L., \& Osborne, J. (2014). Science-related aspirations across the primary-secondary divide: Evidence from two surveys in England. International Journal of Science Education, 36(10), 16091629. https://doi.org/10.1080/09500693.2013.871659

DeWitt, J., Osborne, J., Archer, L., Dillon, J., Willis, B., \& Wong, B. (2013). Young children's aspirations in science: The unequivocal, the uncertain and the unthinkable. International Journal of Science Education, 35(6), 1037-1063. https://doi.org/10.1080/09500693.2011.608197

Falentini, F. Y., Taufik, \& Mudjiran. (2013). Usaha yang dilakukan siswa dalam menentukan arah pilihan karir dan hambatan-hambatan yang ditemui (Studi deskriptif terhadap siswa SMAN 1 Payakumbuh). Konselor: Jurnal Ilmiah Konseling, 2(1), 310-316. https://doi.org/10.24036/02013211266-0-00

Fraser, B. J. (1981). Tosra: Test of science-related attitudes: Handbook. Australia: Australian Council for Educational Research.

Jufrida, J., Kurniawan, W., Astalini, A., Darmaji, D., Kurniawan, D. A., \& Maya, W. A. (2019). Students' attitude and motivation in mathematical physics. International Journal of Evaluation and Research in Education (IJERE), 8(3), 401-408. https://doi.org/10.11591/ijere.v8i3.20253

Kurniawan, D. A., Astalini, \& Anggraini, L. (2018). Evaluasi sikap siswa 
SMP terhadap IPA di Kabupaten Muaro Jambi. Jurnal Ilmiah Didaktika, 19(1), 124-139.

Maharaj-Sharma, R., \& Sharma, A. (2017). Using ICT in secondary school science teaching - What students and teachers in Trinidad and Tobago say? European Journal of Education Studies, 3(2), 197-211. https://doi.org/10.5281/zenodo.251163

Maison, Astalini, Kurniawan, D. A., \& Sholihah, L. R. (2018). Deskripsi sikap siswa SMA negeri pada mata pelajaran fisika. Edusains, 10(1), 160-167.

Manasia, L. (2015). Enjoyment of learning in upper secondary education. An exploratory research. Procedia - Social and Behavioral Sciences, 180, 639-646. https://doi.org/10.1016/j.sbspro.2015.02.172

OECD. (2016). PISA 2015 results: Excellence and equity in education. Paris: PISA OECD Publishing. https://doi.org/10.1787/9789264266490-5-en

Potvin, P., \& Hasni, A. (2014). Interest, motivation and attitude towards science and technology at K-12 levels: A systematic review of 12 years of educational research. Studies in Science Education, 50(1), 85-129. https://doi.org/10.1080/03057267.2014.881626

Pratiwi, N. K. (2015). Pengaruh tingkat pendidikan, perhatian orang tua, dan minat belajar siswa terhadap prestasi belajar bahasa Indonesia siswa SMK kesehatan di Kota Tangerang. Jurnal Pujangga, 1(2), 75-105. https://doi.org/10.47313/pujangga.v1i2.320

Saridewi, K., \& Naqiyah, N. (2017). Pengembangan media pion perencanaan karier pada siswa kelas IX SMP Negeri 1 Besuki. Jurnal BK Unesa, 7(3), 89-98.

Sheldrake, R. (2020). Changes in children's science-related career aspirations from age 11 to age 14. Research in Science Education, 50(4), 1435-1464. https://doi.org/10.1007/s11165-018-9739-2

Shin, S., Rachmatullah, A., Roshayanti, F., Ha, M., \& Lee, J. K. (2018). Career motivation of secondary students in STEM: A cross-cultural study between Korea and Indonesia. International Journal for Educational and Vocational Guidance, 18(2), 203-231. https://doi.org/10.1007/s10775-017-9355-0

Sofyan, A., Yusuf, A. M., \& Daharnis, D. (2018). Tingkat aspirasi karir siswa ditinjau dari jenis kelamin, jurusan dan daerah tempat tinggal. Jurnal Konseling dan Pendidikan, 1(3), 9-27. https://doi.org/10.29210/110800

Swarat, S., Ortony, A., \& Revelle, W. (2012). Activity matters: Understanding student interest in school science. Journal of Research in Science Teaching, 49(4), 515-537. https://doi.org/10.1002/tea.21010

Tyler-Wood, T., Ellison, A., Lim, O., \& Periathiruvadi, S. (2012). Bringing Up Girls in Science (BUGS): The effectiveness of an afterschool 
environmental science program for increasing female students' interest in science careers. Journal of Science Education and Technology, 21(1), 46-55. https://doi.org/10.1007/s10956-011-9279-2

Wang, X. (2013). Why students choose STEM majors: Motivation, high school learning, and postsecondary context of support. American Educational Research Journal, 50(5), 1081-1121. https://doi.org/10.3102/0002831213488622 